\title{
KAINO KALTĖS PAVYZDŽIAI KUNIGO JURGIO PABRÉŽOS PAMOKSLUOSE
}

\section{Remigijus Oželis}

Klaipèdos universitetas

\begin{abstract}
Anotacija
Kaltès juveikimas ir dvasinès ramybès jausena - esmingas žmogaus siekis. Bažnyčia kviečia ị susitaikyma su savimi, kitu ir Dievu; kviečia siekti išganymo - amžinos laimès ir ramybès. Vienas aktyviausiu Bažnyčios mokymo skelbejju buvo kunigas Jurgis Pabrëža (1771-1849), kurio 250-osios gimimo metinès paminètos $2021 \mathrm{~m}$. Tai žmogus, siekęs visomis savo jègomis tarnauti žmonèms, ,kad igytume išganyma per mūsų Viešpatị Jèzų Kristų“ (1 Tes 5, 9). Kun. J. Pabrèža pamoksluose, kalbèdamas apie žmogaus kaltès pajautima ir išsivadavima iš šio slegiančio jausmo, kaip viena iš pavyzdžiu pateikè Kaino istoriją. J. Pabrëža savo pamokslų rinkinyje „Pamokslai vairingose materijose " biblini Kaino varda mini 22 kartus. Iš 48-iu šiame rinkinyje esančiu pamokslų Kainas minimas penkiuose. Kaino nuodèmès ir jo kaltès išgyvenimo pavyzdžiai pateikti aptariant asmens dvasinès gerovès klausimus: kas neturi vilties būti išganytas; kas užmušdamas kita žmogu, nepadaro nuodèmès; kodèl geisti svetimu daiktu yra blogai; kuo blogas pavydus šnairavimas i kita; kuo bloga šventvagiška išpažintis? Remdamiesi Biblijos pasakojimu apie Kaina ir šio pasakojimo pavyzdžiais kun. J. Pabrèžos pamoksluose matome, kad žmogus patiria nerimastinga kaltès išgyvenima kaip pasąmoninga būseną, kurios veikiamas jaučia nesaugumą, bejègiškuma, dvasine kančia, kaip gyvenimo prasmès stoką. Šis kaltès jausmas turi savo priežastį-nuodème, $t$. y. veikima pasaulyje ne pagal prigimties dèsnius.

PAGRINDINIAI ŽODŽIAI: kun. Jurgis Pabrěža, pamokslai, Kainas, nuodèmè, kaltè.
\end{abstract}

\begin{abstract}
Overcoming guilt and feeling spiritual peace is a fundamental human endeavour. The church calls for reconciliation with oneself, others and God and it calls to seek salvation-eternal happiness and peace. One of the most active preachers of the teaching of the Church was priest Jurgis Pabrëža (1771-1849), whose 250th birth anniversary has been commemorated in 2021. He was the man with an ambition to serve others wholeheartedly so that we "receive salvation through our Lord Jesus Christ" (1 Thessalonians 5: 9). Speaking of human guilt and liberation from the oppressive feeling of guilt in his sermons, Fr. J. Pabrëža provided the example of Cain's story. J. Pabrěža mentions the biblical name of Cain in his sermon collection "Sermons on Various Matters" 22 times. Of 48 sermons in this collection Cain is mentioned in 5 of them. Examples of Cain's experience of sin and guilt are provided when discussing the spiritual well-being of a person: who has no hope of being saved; who does not commit sin by killing another man; why is it bad to desire what
\end{abstract}


belongs to another; what evil is there in a jealous sneer towards others; what is wrong with a blasphemous confession? In the biblical story of Cain and examples of this narrative in the sermons of Fr. J. Pabrëža we see that a person experiences a disturbing feeling of guilt as a subconscious state of insecurity, helplessness and spiritual suffering, and as a lack of meaning in life. This sense of guilt has its own cause - sin, i.e. acting in the world against the laws of nature.

KEY WORDS: guilt, sin, Cain, Fr. Jurgis Pabrëža, sermons.

DOI: http://dx.doi.org/10.15181/mtd.v0i7.2307

\section{İvadas}

Žmogus yra veikianti ir kartu nerimastingą kaltès jausmą dèl netinkamų savo veiksmų išgyvenanti būtybė. Kaltès išgyvenimas dvasiškai žmogų slegia, gniuždo. Trokštama susitaikymo: su kitu, savimi ir Dievu. Kaltès įveikimas esmingas žmogiškosios egzistencijos klausimas. Ieškant atsakymų i būties klausimus, teologijos ar psichologijos mokslų sričių problemų diskusijos pradedamos nuo istorijos apžvalgų. I dvasinių problemų kilmę ir raidą gilinamasi analizuojant biblines istorijas. Pavyzdžiui, Leo Madow’as knygą „Pyktis“ (Madow, 1972, p. 3) pradeda priminimu, kad seniausias pykčio ir jo baisių pasekmių pavyzdys yra Biblijos pasakojime apie Kainą ir Abeli, kur sakoma: „Kainas buvo labai piktas ir prislègtas“ (Pr 4, 5). Kaino įvykdyto brolio Abelio nužudymo aprašymu Šventasis Raštas atskleidžia pykčio ir pavydo buvimą žmoguje - pirmapradès nuodèmès, atsiradusios nuo pat žmogaus istorijos pradžios, padarini (Savickij, 2012, p. 16). Kainas yra ne tik pirmasis žmonijos piktadarys, bet kartu ir nusidejèlio simbolis. Tad jo nuodème ir kaltè aptariama visais laikmečiais. Lietuvių filosofas Antanas Maceina sako, kad ,jis atgyja kiekviename nusidedančiame žmoguje, ir kiekvienas nusidejjèlis pakartoja nemirštamus jo žodžius: Argi aš esu savo brolio sargas?“"(2004, p. 381).

Žmogaus patiriama kaltė atskleidžia, kad kažkas padaryta netinkamai. Nuodèmė žmogų žlugdo, tolina nuo amžinojo išganymo perspektyvos. Todèl Bažnyčia savo veikimu kviečia žmones išsilaisvinti nuo nuodèmès ir kaltès jausmo, kviečia ị laimę ir ramybę - amžiną išganymą. Vienas iš išskirtinių išganymo skelbèjų buvo kunigas Jurgis Pabrèža (1771-1849), tikintiesiems teikęs ịtaigius ir įsimintinus, savalaikiškus ir šiuolaikiškus, profesionaliai 
užrašytus ir pasakytus pamokslus, kuriais sieke žmonėms parodyti Viešpatị Jèzų Kristų, atskleisti Jo atneštą išgelbẻjimą. Tai plačių interesų žmogus, kurio siekis buvo visomis savo galiomis tarnauti žmonėms, glaudžioje vienybejje išlaikant mokslą ir tikejjimą skelbti Dievo žodị, ,kad igytume išganymą per mūsų Viešpatị Jėzų Kristų“ (1 Tes 5, 9). Kun. J. Pabrèža pamoksluose, kalbèdamas apie žmogaus kaltès pajautimą ir išsivadavimą iš jos slegiamo jausmo, kaip vieną iš Biblijos pavyzdžių pateikia Kaino istoriją ir jo kaltės patyrimą. Kaino kaltès išgyvenimo pavyzdžiu siekiama žmogų išvaduoti iš nerimastingos kaltès būsenos. Tad šio tyrimo objektas - kunigo J. Pabrěžos pamokslų rinkinio „Pamokslai vairingose materijose“" pamokslai. Tikslas atskleisti kun. J. Pabrezžos pateiktus Kaino nuodemingos būsenos ir kaltės pajautimo pavyzdžius.

Kun. J. Pabrěža, kad atskleistų temą, dažniausia taiko katechetinį metodą: pateikia klausimus ir ị juos atsako. Šiuo pasirinktu klausimų ir atsakymų metodu aiškiai perteikia tai, ką žmogus turi žinoti. Laiko ženklus skaitydamas ir juos interpretuodamas Biblijos šviesoje pamokslininkas J. Pabréža ne tik kalbejjo apie Dievą, bet pamažu klausytojus vedẻ link kalbèjimosi su Dievu Jèzuje Kristuje, o per tai - i asmens dvasinę gerovę.

\section{Biblijos pasakojimas apie Kaino nuodėmę}

Prieš aptariant Kaino kaltès pavyzdžius kun. J. Pabrèžos pamoksluose, pirmiausia trumpai pažvelkime ị patị Biblijos pasakojimą apie Kaino nuodèmę.

Pirmujų žmonių (Adomo ir Ievos) nuodėmė nepanaikino religinės žmogaus savimonès: Kainas ir Abelis spontaniškai ėmė atnašauti ir garbinti, aukodami Dievui savo darbo vaisius: piemuo Abelis aukojo avinèlius, žemdirbys Kainas - žemès vaisius. Bet kai Abelis iš tikrųu garbino, galvodamas tik apie Dievą, buvo visiškai paniręs Dieve, Kainas garbino pasilaikydamas sau vyresniojo sūnaus viršenybę, jautėsi turịs prižiūrèti brolị. Jis atliko tik

Pamokslai vairingose materijose, sakyti Ambroziejaus Pabrėžos. (2020). Vilnius: Lietuvių kalbos institutas. (Pamoksłay Wayringosy materyjosy ąt rožniu wyitu, iwayriusy łaykusy Sakity par Kónyga Ambroźiejó Pabreża Tercyjorió Zokana Szwęta Tiewa Prąćźyszkaus). Toliau kun. J. Pabrēžos pamokslai bus cituojami iš šio pamokslų rinkinio. 
išorinius liturginius veiksmus, garbino „žvairuodamas“: viena akis nukreipta ị Dievą, kita - ị Abelị. Kainas garbino ne visa širdimi, bet rūpinosi tuo, ką ir kaip daro Abelis: negarbina Dievo, bet smalsiai domisi Abeliu ir ima jam pavydèti. İ Kaino širdị ịsiskverbęs pavydas skatina nuliūdimą, kartu kreipia brolžudystės link. Taigi pirmoji žmogžudystė yra tiesioginè pavydo pasekmė (Oželis, 2012, p. 280-281). Ši pavydo nuodèmès ir iš to kylančios kaltès teologija perteikta Senojo Testamento Pradžios knygoje:

Laikui bėgant, Kainas aukojo Viešpačiui žemės derliaus atnašą, o Abelis savo ruožtu aukojo rinktines savo kaimenès pirmienas. Viešpats maloniai pažvelgé ị Abelị ir jo atnašą, bet ị Kainą ir jo atnašą nepažvelgè. Todèl Kainas buvo labai piktas ir prislėgtas. Viešpats užkalbino Kainą: „Dẻl ko tau taip pikta? Kodèl esi taip prislègtas? Jei gera darai, argi nebūsi pripažintas? Bet jei gero nedarai, prie durų iš pasalų tykoja nuodèmè. Ji geidžia tavęs, bet tu gali ją įveikti.“”

Kainas tare savo broliui Abeliui: „Išeikime ị lauką...“ Pasiekus lauką, Kainas pakilo prieš savo brolị ir jị užmušè. Tuomet Viešpats paklausẻ Kainą: „Kurgi tavo brolis Abelis?“ - „Nežinau! Argi aš esu savo brolio sargas!?“ - jis atsakè. O Viešpats jam tarè: „Ką tu padarei? Tavo brolio kraujas šaukiasi manęs iš žemès! Todèl būk prakeiktas toli nuo žemès, kuri atvèré savo burną priimti tavo brolio kraują iš tavo rankos. Kai tu dirbsi žemę, ji nebeduos tau daugiau savo derliaus. Tu būsi bèglys ir klajūnas žemèje.“ Kainas atsakẻ Viešpačiui: „Per daug didelè man bausmé, jos pakelti negaliu! Šiandien išvarei mane nuo žemès, aš turiu slèptis nuo tavo veido ir tapti bėgliu bei klajūnu žemėje, - kas tik mane sutiks, galès mane užmušti.“ Tuomet Viešpats jam tarè: „Taip nebus! Jei kas užmuštu Kainą, už Kainą bus atkeršyta septynis kartus.“ Ir Viešpats paženklino Kainą žyme, kad kas nors, jį užtikęs, neužmuštų. Tada Kainas paliko Viešpaties artumą ir apsigyveno Nodo krašte, ị rytus nuo Edeno (Pr 4, 3-16).

Po ịvykdytos brolžudystès Kainą regime patiriantị nuodèmès pasekmes, išgyvenantị kaltę. Kainą prakeikia Dievas ir pati žemé, kuri jam nebeduos savo derliaus. Jis nubaudžiamas: turès gyventi dykvietėse ir tyruose. Smurtas ir žudymas iš pamatu pakeičia žmogaus aplinką. Žemè, užuot buvusi Edeno sodu (plg. Pr 2, 15), pertekliaus, darnių asmeninių santykių ir draugystès su Dievu vieta, tampa Nodo kraštu (plg. Pr 4, 16), t. y. trūkumo, vienatvès ir atskyrimo nuo Dievo vieta. Kainas nuo šiol bus bėglys ir klajūnas žemėje (plg. Pr 4, 14), 
ji visada lydès netikrumas ir nerimastis. Tačiau Dievas, būdamas gailestingas net bausdamas, paženklino Kainą žyme, kad kas nors, jị sutikęs, neužmuštų (plg. Pr 4, 15). Taip pažymejjo jị aiškiu ženklu ne tam, kad pasmerktų kitų neapykantai, o kad apsaugotų nuo norinčiųjų, kuriuos užvaldęs troškimas atkeršyti už Abelio mirti, jị nužudyti (Mellinkoff, 1981, p. 12; Junior, 2020, p. 661-662). Vadinasi, net žmogžudys nepraranda asmens orumo, Dievas pats imasi užtikrinti asmens teises ir orumą. Kaip tik šioje vietoje pasireiškia paradoksalus Dievo gailestingo teisingumo slèpinys (Popiežius Jonas Paulius II, 1995, nr. 9). Bažnyčios Tèvas ir Mokytojas šv. Ambraziejus (340-397), kurio vardą pasirinko kun. J. Pabrėža, rašè, kad vos pripažinus nusikaltimą, pačioje nuodèmingo brolžudystės veiksmo užuomazgoje, Dievo malonès dieviškasis ịstatymas turi būti praplečiamas. Kaltinamajị iškart nubaudus, teisingumą vykdantys žmonès niekaip negalès paisyti kantrybès ir susilaikymo, iš karto pasmerks nubausti. Tuo tarpu Dievas pavare Kainą sau iš akių - pasiunte jị klajoti toli nuo gimtujų vietų, taip jo gyvenimas, buvęs kupinas žmogiškojo gerumo, įgavo grubaus laukinio žvėries būvị. Dievas pasirinko nusidejèlio pasitaisymo, o ne jo mirties kelią, netroško, kad žmogžudys būtų nubaustas ịvykdant dar vieną žmogžudystę (cit. iš Savickij, 2012, p. 25).

Nutraukus brolystès ryši, atsiveria kelias ị skausmingas konflikto, išdavystès, neapykantos patirtis. Nuodèmè tartum išmeta žmogų iš bendrystès. Atstūmimas, socialinè atskirtis yra nuodėmingo pasaulio išraiška - tai jautrumo Dievui ir žmogui nuosmukis, nuodėmès struktūra pasaulyje (Neverdauskè, 2015, p. 8-14). Šis biblinis pasakojimas apie Kainą ir Abelị yra tokios neigiamos pasekmės pavyzdys. Dievas klausia Kaino, užmušusio Abelį: „Kurgi tavo brolis Abelis?“ (Pr 4, 9a). Popiežius Pranciškus sako: „Šito Viešpats ir toliau klausia kiekvienos kartos. Deja, kiekvienoje kartoje nepaliauja kartotis dramatiškas Kaino atsakymas: „Nežinau! Argi aš esu savo brolio sargas?“ (Pr 4, 9b). Ryšio tarp brolių nutraukimas yra bjaurus ir negeras dalykas žmonijai. Taip pat šeimoje - kiek brolių ginčijasi dèl mažmožių ar palikimo, tada jie tarpusavyje nebesikalba, nebesisveikina“" (Popiežius Pranciškus, 2018, p. 27).

Pereikime prie konkrečių Kaino kaltės pavyzdžių kun. J. Pabrēžos pamoksluose. 


\section{Kas neturi vilties būti išganytas?}

Pradžios knygoje slegianti būsena padarius nuodėmę išreiškiama beviltiškais Kaino žodžiais: „Per daug didelè man bausmè, jos pakelti negaliu!“ (Pr 4, 13). Tai vilti praradusio žmogaus kančios išraiška. „Pamoksle apie Pirmo Dievo įsakymo antrą dalį, tai yra apie tikẻjimą, viltị, meilę ir Dievo garbę “2 , kun. J. Pabrèža kelia klausimą ir pateikia viltingą atsakymą apie išganymo galimybę:

Klausimas: „Kurie nusidèjèliai nebeturi jokios vilties būti išganyti?“ Atsakymas: „Tie nusidejèliai, kurie, paskendę nuodėmėse, mąsto savo širdyje, kad yra praradę dievobaimingumą, kaip Kainas sakè: didelis yra nešvarumas mano, niekaip tad atleidimo negaliu atrasti. ${ }^{3}$

Kun. J. Pabrèža, konstatuodamas situaciją, kad kai kurie, kaip ir Kainas, praranda viltị, siekia padèti žmonèms atrasti viltị gyvenime ir viltị dèl amžinojo gyvenimo. Bažnyčios mokymo užduotis, žmogui išgyvenant dèl kaltės, kai apimtas nevilties, patvirtinti tikejjimo galią ir parodyti vilties pagrịstumą. Dievas „trokšta, kad visi žmonès būtų išganyti ir pasiektų tiesos pažinimą. Vienas yra Dievas ir vienas Dievo ir žmonių Tarpininkas - žmogus Jėzus Kristus, kuris atidavė save kaip išpirką už visus“ (1 Tim 2, 4-6), rašo šv. Apaštalas Paulius. Tad Bažnyčia savo mokyme primena, jog „Dievas trokšta, kad visi būtų išganyti per tiesos pažinimą. Išganymas randamas tiesoje. Paklūstantys tiesos Dvasiai jau eina išganymo keliu“ (Tikejjimo mokslo kongregacija, 2000, nr. 22). Jėzus Kristus atpirko visus, kad visi pasiektų iš-

2 Pamoksłós Apey Óntra Dali Pyrmoiy Prisakima Dyiwa: tay ira: Apey Wiera, Wylty, Meyly yr Garby Dyiwa. - Sakits Satąusy taykó Atpósku 40. Adinu, par Sekmynes. Metusy 1825 , p. 57-96. Čia ir toliau pamokslu puslapių numeracija pateikiama pagal originalią kun. J. Pabrèžos pamokslų rinkinio puslapių numeraciją.

3 „Kł. Kóryi grieszyi par nebtórieiyma niejokios nadieiys Jszganima? - Ats. Tyi griesznikay, kóryi budamis griekusy paskędy, dumo sawa szyrdieiy łosnay bezbażnós Kain taridamis: dydesnis ira nepaczcziwóms móna, nekóu kad begalieczió atleydyma atrasty." Pamokstós Apey Óntra Dali Pyrmoiy Prisakima Dyiwa: tay ira: Apey Wiera, Wylty, Meyly yr Garby Dyiwa. - Sakits Sałatusy taykó Atpósku 40. Adinu, par Sekmynes. Metusy 1825, p. 73. Čia ir toliau tekste J. Pabrèžos pamokslų citatos šio straipsnio autoriaus laisvai perteikiamos dabartine lietuvių kalba, išlaikant pirminę minties prasmę. 
ganymą. Tad viltis būti išganytam skirta visiems. Tačiau Dievas, kviesdamas ị išganymą, laukia žmogaus laisvo atsako.

Jėzus sakè: „Kiekviena nuodėmè ir piktžodžiavimas bus žmonèms atleisti, bet piktžodžiavimas Dvasiai nebus atleistas. (...) kas kalbètų prieš Šventają Dvasią, tam nebus atleista nei šiame, nei būsimajame gyvenime“" (Mt 12, 31-32). Šventosios Dvasios tikslas - išgelbèti žmogų iš nuodèmès ir vesti, kad ji apimtų amžinos laimès būsena. Žmogui nuolat atmetant Šventosios Dvasios kvietimą ir užkietinus savo širdị, Šventosios Dvasios veikimas tampa nebepastebimas, ir asmuo galutinai pražūva. Tas, kuris ieško Dievo, šios nedovanotinos nuodėmès nedaro (What Does the Bible Say About..., 2020). Katalikų Bažnyčia moko, kadangi gailestingumas yra begalinis, nėra tokio nusikaltimo, už kurị negalètų būti atleista. Jei už nuodėmę Šventajai Dvasiai, apie kurią kalba Jèzus, negali būti atleista, tai tik todèl, kad ji pagrịsta atleidimo atmetimu: atmetu man suteikiamą atleidimą ir nesutinku jo suteikti kitam. O juk Šventoji Dvasia pati yra Atleidimas - atleidimas, kuris negali savęs primesti (Ange, 2006, p. 85).

\section{Kuris užmušdamas kitą žmogų nepadaro nuodėmẻs?}

„Kainas pakilo prieš savo brolị ir jị užmušě“ $(\operatorname{Pr} 4,8)$. „Pamoksle apie Penktą Dievo įsakymą“4 aptariamas Dekalogo ịsakymas „Nežudyk“. Kun. J. Pabrěža gilinasi ị tai, ar visada nužudydamas kitą žmogus yra kaltas.

Klausimas. Kada ir kokiais atvejais užmušus kitą gali būti laisvas nuo nuodèmès? (...) Atsakymas: Jeigu kas per nelaimę, per kokị nelaimingą atsitikimą užmuštų kitą, gali nenusidèti per tokị užmušimą pagal Šventojo Rašto mokymą (İst 19, 4-5). Nes tas, kas to jokiu būdu nenorèjo, lieka be nuodèmès. $^{5}$

4 Pamokstas Apey Pękta Prisakima Dyiwa. - sakits ónt Jubileusza dydzioiy. Mosiediey. Metusy 1826, p. 129-144.

5 „Kł. Kóumet, yr kokiusy prisytropyiymusy óżmuszies kyta, gał buty lóusós nóu grieka? - Ats. Kad kas ysz necziestys, ysz necziesliwa pripodka koky, óżmusztu kyta gał nesógrieszity par toki óżmuszyma, pagał mokima Raszta Szwęta. (Deut. XIX. 4. etc.:). Nes tay, kas dedas niekó budó nenoręt, stojes be grieka." Pamoksłas Apey Pękta Prisakima Dyiwa. - sakits ónt Jubileusza dydzioiy. Mosiediey. Metusy 1826, p. 131. 
Čia kun. J. Pabrèža remiasi Senojo Testamento Pakartoto įstatymo knygos žodžiais, kuriais pristatoma netyčinè žmogžudystė:

Šitoks yra atvejis žmogžudžio, kuris gali ten nubėgti ir savo gyvybę išgelbėti: kai kas nors netyčiomis yra užmušęs savo artimą, su kuriuo niekad nèra buvęs priešas. Tarkime, nueina kas nors su artimu ị mišką malkų pasikirsti ir jam, pakèlus kirvị medžiui kirsti, kirvis nuslysta nuo koto, mirtinai užgaudamas jo artimą (İst 19, 4-5).

Vis dèlto, nors žmogžudystė ịvykdoma netyčia, žmogus yra atsakingas dèl blogą veiksmą nulèmusių aplinkybių. Žmogiški veiksmai, kurių objektai prieštarauja asmens gėriui, moralineje teologijoje vadinami vidujai blogais veiksmais: jie yra tokie visada ir patys savaime, t. y. dèl paties jų objekto, nepaisant paskesnių veikiančiojo intencijų ir aplinkybių, tad griežtai neleistini. Iš tokių veiksmų paminima žmogžudystè. Tačiau, jei veiksmai vidujai blogi, gera intencija ar konkrečios aplinkybės gali tą blogumą sušvelninti. Taigi veiksmo moralumą lemia ir tam tikros konkrečios aplinkybès. Jos moraliniu požiūriu svarbios, jei didina ar mažina gerą arba blogą rezultatą arba sukelia papildomų blogų padarinių, arba sudaro progą tokiems padariniams. Vienas ar kitas žmogaus veiksmas, esant tam tikroms aplinkybėms, gali būti skirtingai vertinamas (Narbekovas, 2004, p. 18-21). Todèl, jei žmogžudystė net ịvykdyta netyčia, kaip toliau teigia J. Pabrěža, žmogus gali būti kaltas dèl aplinkybių, lèmusių blogas pasekmes:

Vienok ir toje srityje, kad nenusidetum, labai didelio reikia atsargumo. Nes, nors žmogus ir nenorètų kito užmušti arba sužeisti, bet jei darytų tokị darbą, yra negeras dalykas, iš kurio gali kilti nusikaltimas, toks visados kaltas būtų užmušęs žmogų. O tokie yra tie: 1 . Kurie šautuvą ar pistoletą užtaisytus laikẻ namuose. 2. Kurie pagrobę šautuvą užtaisymą tikrina ị žmogų, ir tokie, kurie nežinodami, šautuvas yra užtaisytas ar ne, vis tiek sprigčioja. 3. Kurie šautuvą užtaisytą laiko kur nors iškištą arba pamestą. 4. Kurie, pašaudyti išèję, su užtaisytu šautuvu nesielgia visų atsargiausiai. Oi, šautuvas, šautuvas vertas būti prakeiktas, kiek daug per jị žmonių užmuštų yra! O visi tokie nusikalteliai sako, kad tai atsitiko netyčia: bet pas Dievą retas iš tokių užmušèjų bus laikomas ne žmogžudžiu. ${ }^{6}$

6 ,Wyinok yr tamy daykty, kad nesógrieszity; łabay dydzios reyk óstrażnibys. Nes norint żmogós yr nenorietu kyta óżmuszty, arba sókalieczity: ale iey daritu toki 
Kaltės pajautimas susijęs su veiksmais, t. y. su tuo, ką žmogus daro netinkamai (Nauta, 2009, p. 66). Žmogaus patiriama vidinè neramybè ir sąžinès graužatis rodo jị esant kaltą. Kaltès išgyvenimas rodo pakenkimą egzistencijos plotmèje. Dažniausia žmogų kaltina jo paties sąžinè, o bausmès vykdytoju, jeigu negebama teisingai interpretuoti kaltintojo ar laikytis jo nustatytų normų, tampa pats žmogus. Ši bausmè - savęs atstūmimas, negebèjimas tinkamai savimi rūpintis, vis labiau pasąmoningai stumiant save „ešafoto“ link (Ivanovienè, Juškienè, 2018, p. 115, 128). Toliau pamokslininkas J. Pabrèža, kalbėdamas apie asmens patiriamą kaltę nužudžius kitą, vèl pateikia Kaino pavyzdį:

Šventasis Raštas pateikia pirmą žmogžudystę, kurią įvykdè Kainas užmuždamas savo tikrą broli Abelị. Taip pat nurodo ir antrą žmogžudystę, padarytą Lamecho, kuris užmuše Kainą pirmaji žmogžudị. Abu žmogžudžiai nusidejo: bet tarp jų nuodėmès buvo skirtumas: Kainas, užmušdamas Abelị, užmuše ji tyčiomis, iš didelio pykčio ir neapkentimo jo; o Lamechas, užmušdamas Kainą, užmušè jị nenorédamas, per nelaimingą atsitikimą. Tai toks būdas.

Turẻjo Lamechas dideli norą užsiimti medžiojimu, užmušti žvèris ir paukščius šaudydamas iš lanko vilkus. Vieną kartą išejo ị medžioklę, pamatè, kad kažkas juda krūmuose: šauna tada ị tą judantị žvérị, bet vietoj žvėries, Kainą užmušo, arba kitą žmogų (nes apie tai kai kurie sako, kad Lamechas Kainą užmušo. Tačiau kiti kitaip sako, kad ne Kainą, bet koki kitą žmogų turèjo užmušti (Komentaras Antoine Augustin Calmet).

Apsvarstykime dabar: kuris kaltesnis yra iš tų dviejų žmogžudžių? Atrodo, kad Kainas. ${ }^{7}$

darba, yr daykta negera, ysz kório gał stotyis razbaynykiste, toks wysados kałts butu óżmuszta żmogaus. - O tokeys ira tyi: (a) 1 a Koryi striełbas arba pyszteletas óżdaritas łayka nómusy. - 2ra Kóryi pagrobyi striełba óżdarita mieróu i żmogó, yr tyi, kóryi neżynodamis ar striełba ira óżdarita, ar ne, wyinok sprygyn. 3ti Kóryi striełba óżdarita łayka kór ikyszta, arba pamesta. - 4a Kóryi ónt strielczistys yszejy, só striełbó óżdaritó, neełgas wysóóstrażniausey. - Oy striełbas, striełbas, wertas but yszkeykyma, kayp daugel par anas jau żmoniu óżmusztu rądas! O wys sakos razbaynikay tokyi, kad tay stojos ysz neticziu: bet pri Dyiwa rets ysz tokiu óżmuszieju tebus paskaytits ne óż razbaynika." Pamoksłas Apey Pękta Prisakima Dyiwa. - sakits ónt Jubileusza dydzioiy. Mosiediey. Metusy 1826, p. 131.

7 „Raszts Szwęts priwed pyrma razbaynykisty, kóryi papyldy Kains óżmuszdams tykróuji Broli sawa Abló. - teypojaus priwed yr óntra razbaynykisty papyldita par Lamech, kórs óżmuszy Kaina pyrmóuji razbaynika. - Abódo tóudó razbay- 
Išties Šventajame Rašte nekalbama, kad Lamechas užmušè Kainą. Tiktai pats Lamechas teigia, kad ,užmušiau žmogų už žaizdą, bernioką už įdrèskimą، $(\operatorname{Pr} 4,23)$. Kaip nurodo kun. J. Pabrèža, jis čia remiasi prancūzų benediktinu Antoine Augustin'u Calmet'u (1672-1757), kuriam savo laiku buvo pavesta aiškinti Šventajj Raštą Moyenmoutier'o ir Munster'io abatijose. 1748-1750 m. Paryžiuje pasirodè naujas Biblijos leidimas, vadinamas Venso Biblija (La Bible de Fence), lotynų ir prancūzų kalbomis. Joje pateiktos benediktino A. A. Calmet'o ịžangos ir paaiškinimai. Lietuvos nacionalinejje bibliotekoje saugoma pirmoji šios redakcijos laida. Tai viena vertingiausių Nacionalinejje bibliotekoje saugomų XVIII a. Biblijų (Misiūnienė, 2011, p. 61). Galima kelti prielaidą, kad J. Pabrěža, studijuodamas Vilniuje, susipažino su šiuo Biblijos leidimu ir komentarais.

\section{Kodèl geisti svetimų daiktų yra blogai?}

Anot teologo Eli Stanley’aus Jones'o: „Kas nieko negeidžia, tam priklauso viskas. Neturèdamas nieko, jis turi viską, ịskaitant ir pati gyvenimą... Jis turtingas, bet turtingas ne savo turto gausybe, o savo troškimų menkumu“ (cit. iš Plett, 2013, p. 122). „Pamoksle apie Dešimt Dievo ịsakymų, sakytame Mosėdyje per Didijj Jubiliejų 1826 metais“ ${ }^{\text {“8 }}$ kun. J. Pabrèža kalba apie netinkamą geidimą svetimo turto. Pirmiausia pamoksle kelia klausimą:

nikó sógrieszyiy: ale tarp grieka anóudóus tas bówa kytonyszkóms: iogey Kains óżmuszdams Abló, óżmuszy ji ticziomis, ysz dikos złastys yr neapkątas ónt jo: o Lamech óżmuszdams Kaina, óżmuszy ji nenoriedams, ysz necziestys: o tay tokió spasabó: Torieiy Lamech dydy ókata bowityis strielczisty, muszty żwieris yr paukszczius szaudidams só seydokó wilicziemis. Wyna siki yszejys ónt szaudiklys, yszwida, kad każynkas kósz krumalusy: szaun tada i tóu kószątiji żwieri, bet wyito żwieryis, Kaina óżmusz, arba kyta żmogó. (: nes tamy daykty noris nekóryi prowyi kad Lamechs Kaina óżmuszy, wyinok, kyty kyteyp saka, iog ne Kaina, bet kyta koki żmogó tórieiy óżmuszty (Comment. Calmet. in Genes. Cap. 4. ver. 24.) - Apsudikyt dabarczióu: katras kaltesnis ira ysz tu dwyju razbayniku? Rodos, jogey Kains.“ Pamokstas Apey Pękta Prisakima Dyiwa. - sakits ónt Jubileusza dydzioiy. Mosiediey. Metusy 1826, p. 131-132.

8 Pamokstós Apey Deszimta Prisakima Dyiwa Sakits Mosiedie łaykó Dydziojy Jubileusza Metusy 1826, p. 279-294. 
Kokią žalą daro negeras geidimas svetimų gèrybių? Atsakymas. (...) Blogas geismas svetimų daiktų naikina meilę artimui visiškai, o ị meilès vietą stato neapkentimą niekuo nekalto asmens, kuris vertas būti labai mylètinas ir gerbtinas. Tas blogas geismas naikina meilę artimui, veda žmogų prie garbės atėmimo, barimosi, mirties linkejimo, ir visokių kitų negerovių: užgauliojimų, barimosi ir visokių nuostolių. Tas bedieviškas geidimas veda ị plūdimąsi, grobimą, sužeidimą, žudymą, ir ị visokių skriaudų ivykimą. ${ }^{9}$

Toliau netinkamo geidimo priežastị ir pasekmes nusako Kaino pavyzdžiu, remdamasis Biblijos žodžiais: „Viešpats maloniai pažvelgè ị Abeli ir jo atnašą, bet ị Kainą ir jo atnašą nepažvelgè. Todèl Kainas buvo labai piktas ir prislègtas“ (Pr 4, 4-5). Pats Kaino pyktis atskleidžia, kad širdyje jis dèl atnašaujamos aukos abejoja, tarsi Dievas negalètų pasirinkti - priimti auką ar jos nepriimti. Čia kalbama apie pirmapradès nuodèmès padarinius, norą savo aukomis valdyti patị Dievą: aukodamas auką žmogus nori nurodyti Dievui, ką šis privalo su ja daryti, jis bando kažką gauti, sudaryti mainų sutartị. Aukodamas Dievui auką žmogus kèsinasi ị Dievą, ị Jo asmens laisvę. Aukojant išties pamaldžiai, visiškai pripažįstant Dievo asmenị, kuriam aukojama, nepykstama ant kito dèl jo atnašaujamų aukų (Gudaitytè, 2007, p. 84).

Paveikslą tos tiesos parodo ant savęs nelaimingas Kainas, Adomo sūnus. Kaip matome, jog teisingas jo brolis Abelis žiūrèjo ị Viešpatị Dievą ir jog mylintis Dievas jo atnašas prièmé, palaimindamas gausiai jo turtą $(\operatorname{Pr} 4$, 4-5). Supyko labai už tai ant savo brolio, persimainè jo veidas ir puolè ị tokią bedievystę, jog niekuo nekaltą savo brolị išsivede ị laukus, užmušè jị negyvai. Klausykite, mylimiausieji! Kas čia Kainą atvedè ị tokị didelị ininiṣ̌ ir pyktị ant savo brolio, kad atmetè ị šalị širdies myliširdystę ir bro-

9 „Kokes yszkadas dara negers geydyms swetyma geribys? Ats. (...) Pykts geydólis swetyma dayktu, naykyn Meyly artyma sówysó czistay, o i wyita meylys iweys neapkąta pagalaus ónt niekó nekałtu asabu; kórios wertas but dydey miliety yr szynawoty: - Tas pykts geydólis ysznaykynys meyly ónt artyma, wed żmogó ónt szłowys draskima, ónt bórczyiyma, ónt żiczyiyma smerty, yr wysokios niecziestys kytam: ónt zwaydyiymos, prowoiymos yr wysokiu nezgadu. - Tas bezbażnós geydyms wed i łopynstwas, grebeżius, sóronyiymus, razbaynikistes, yr ónt wysokiu kridwu dasyleydyma." Pamokstós Apey Deszimta Prisakima Dyiwa Sakits Mosiedie łaykó Dydziojy Jubileusza Metusy 1826, p. 287. 
lišką meilę, išdrịso užmušti jị ir jo kraują pralieti, ir per tai užsitraukẻ prakeikimą Dievo ir amžiną negarbę užsitraukè ant savęs nuo Dievo? Šitam viena tik priežastis, sako Šventasis Raštas, jog Viešpats Dievas maloniai Žvelgè ị Abelio auką, o ị Kaino aukas nepažvelgè. ${ }^{10}$

Dekalogo ịsakymas „Negeisk svetimo turto“ reikalauja vidinės laikysenos, kurią žymi pagarba kito nuosavybei, ir draudžiamas godumas, svetimu gèrybių nežabotas geidimas bei pavydas, kurio esmè - nusiminimas dèl kito turimų gèrybių ir besaikis troškimas jas pasisavinti (Katalikų Bažnyčios Katekizmas. Santrauka, 2007, nr. 531). Dešimtasis dekalogo įsakymas „Netrokši (...) bet ko, kas priklauso tavo draugui“ (Ist 5, 21) reikalauja pagarbos sukurtoms gèrybėms, kurias Viešpats patikèjo visai žmonių giminei, pagarbos kitų darbo vaisiams. Skatinamas žmonių garbingumas bendraujant su kitais, raginama nepavydèti svetimo turto ir mąstant ne tik apie savo laimę būti pasirengusiems padaryti laimingus kitus (Forte, 2002, p. 36).

Kuo gi tau nusikalto brolis tavo, pesimistiškai nusiteikęs Kainai? Jog Dievas jo atnašas prièmé? Argi už tai nevertas buvo, idant už tai tu jị labiau mylètum ir saugotum, brangintum? Jog buvo toks geras ir teisingas Dievo akyse, kad jo aukas maloniai prièmé? Bet nepriimtas tamsumas piktai geidžiančio žmogaus! Kainas dèl to nekentè savo brolio, jog ji matė gerą esantị ir pasitikintị Dievu aukojant Jam aukas, o pats Kainas buvo piktas ir nenorèjo eiti jo pèdomis. ${ }^{11}$

10 „Paweyksła tos tyisos parody ónt sawys necziesliws Kains Sunós Adoma. Tas kad regieiy, iog teysings Ablós brolis jo pasydaboiy Ponóu Dyiwou, yr iog miłay Dyiwas jo afieras priimdynie, błagasłowidams anam gausey ónt jo tórta (:Genes. 4. 5.) óżsyrustyna łabay dydey óż tatay ónt Broly sawa, atsymayny weyds jo, yr i toky ipóuly bezbażnasti, iogey niekó nekałta Broli sawa yszwedyis i łaukus, óżmuszy ji akrutnay. - Uwożokyt Milausyijy! Kas cze Kaina atwedy i teyp dydi padukyma yr złasti ónt broly sawa, iog atmetyis i szali szyrdi miłaszyrdistys, yr meyly brolyszka, atsywożyiy óżmuszty ji, yr jo krauji pralyity, o par tay dóbółta prakeykyma Dyiwa yr ómżyna yr doczesna óżtraukty ónt sawys nóu Dyiwa? szytay ta wyina tyktay destys, saka Raszts Szwęts, jog Pons Dyiws łoskawoms akymis stebiejos ónt afieru Ablaus, o ónt afieru Kaina anie żwełgty nepażwelgy.“ Pamokstós Apey Deszimta Prisakima Dyiwa Sakits Mosiedie łaykó Dydziojy Jubileusza Metusy 1826, p. 287.

11 „Kasgi tay do nóusydieiyms Broly tawa bezbażnas Kain? iogey Dyiwas afieras jo priimdynieiy? Argi óż tatay newerts bówa, idant óż tatay tó ji dydziaus milietómi, 
Pateikęs Kaino nuodèmès ir jo išgyvenamos kaltès pavyzdį, J. Pabrèža nurodo, kad panašiai elgiasi ir klausytojai:

Tegul kuris, ar tai brolis, ar kaimynas, ar kitas mūsų artimas, patenka ị kokio didelio pono malonę, tegul gauna už patikimą savo pasitarnavimą kokị atlygị: tegul nusiperka kokị gabalèli žemès, tepasistato geresnius pastatus, tepadidina sau gerų lešų pelną ir madingumą savo. Jau visas sodžius, beveik visi kaimynai ir pažįstami dèl to liūdite labai, puolate visi ị didelị pyktị ir neapykantą, visi jo garbę prieš kitus draskote ir stengiatès, kaip ji kuo greičiau iš malonès išmesti ir jo atlygị išplëšti. Bet ką jums tas kaimynas pikto padarè? Niekur jūsų nenuskriaudè. Nei vieno iš jūsų nepapiktino. O galbūt ne vienam jūsų daugel gero parodè. Dẻl ko jūs ant jo leidžiate liežuvị piktą? Dẻl ko jūs norite jị pražudyti? Tai viena ir ta pati yra priežastis, kuri buvo Kainui, kai pyko ant brolio savo. Kaip Kainas pyko ant brolio savo, jog jis turèjo Dievo malonę, jog Dievas ji laimino, taip ir jūs dẻl to pykstate, kad Dievas pažiūrèjo ị brolị, i kaimyną jūsų dèl jo dorybių ir tarnystès ir jị palaimino turtuose jo. ${ }^{12}$

yr pawożotómi, szynawotómi? iogey bówa teypo gers, yr sprawedliws akysó Dyiwa, kad jo afieras milesney priimdynieiy? - Bet, o! nepaimta aklibe pykta geydóly żmogaus! - Kains diełto nekęt broly sawa, iog ji regeiy gera esąt yr wierna dieł Dyiwa pri atidawynieiyma Jem afieru, o pats Kains bówa pykts, yr nenorieiy eyty jo piedomis.“ Pamoksłós Apey Deszimta Prisakima Dyiwa Sakits Mosiedie łaykó Dydziojy Jubileusza Metusy 1826, p. 287-288.

12 „Tegół kórs, ar tay Brolis musó, ar Sósieds, ar kyts musó artyms ipół i łoska pri koky Pona Dydy, tegół gaun óż wiernas sawa pasługas, koky órąda: te priperkas sau koki szmoteli żemys, teyszbódawojes geresnius trobesnius, tepadaugyn sau geró spasabó pełna, yr majętnasti sawa: jau ciełoy Akaliczioiy, mażny wysy sósieday, yr pażistamis, ysz to smutnyjes łabay, pół wysy i dydy złasti, yr neapkąta, wysy jo szłowy prisz kytus draska, yr storojes kayp ji kóu greycziausey ysz kyino łoskas yszmetinty, yr jem pasywedyma yszplieszty. - Ale kóu jums tas Sósieds pykta padary? Niekamy jusó nepakridwyiy: niewyinam ysz jusó neisypryklyiy: o rasi newyinam ysz jusó daugel gera swieczyiy. Óżkóugi jus ónt jo teyp leydat lyiżówi pykta? Óż kóu noryt ji prapóldity? - Tatay wyina pati wysa to ira destys, kóri bówa yr Kainóu pri złastyiymos ónt Broly sawa: kayp Kayns złastyjos ónt Broly sawa, iog Jis tórieiy łoska pri Dyiwa, iog Dyiwas Jem błagasłowyiy: teyp yr jus óż tatay tyktay złastyjeties, iog Dyiwas żwylkterieiy ónt Broly, yr sósieda jusó, ónt jo Cnatu yr zasługu, yr jem pabłagasłowyiy tórtusy jo." Pamoksłós Apey Deszimta Prisakima Dyiwa Sakits Mosiedie łaykó Dydziojy Jubileusza Metusy 1826, p. 288. 
Kaltè visada susijusi su taisyklių, kurios skirtos tam, kad apsaugotų bendrą gèrị, pažeidimu. Šios taisyklès būtinos kaip socialinė garantija ir tvarkos apsauga (Nauta, 2009, p. 66). Dešimtuoju ịsakymu draudžiama geisti svetimų gèrybių, nes iš to kyla septintuoju ịsakymu „Nevok“ draudžiami vagystė, plëšikavimas, sukčiavimas. „Akių geismas“ (1 Jn 2, 16) sukelia prievartą ir neteisybę. Dešimtajame įsakyme kalbama apie širdies ketinimus, drauge su devintuoju šis įsakymas yra kitų İstatymo įsakymų santrauka (Katalikų Bažnyčios Katekizmas, 2012, nr. 2534).

\section{Kokị blogị lemia pavydus šnairavimas ị kitą?}

„Viešpats maloniai pažvelge ị Abelị ir jo atnašą, bet ị Kainą ir jo atnašą nepažvelgè. Todèl Kainas buvo labai piktas ir prislègtas“ (Pr 4, 4-5). Kaino reakcija į netikètą jo netinkamo aukojimo atmetimą buvo įtūžis ir pyktis. Jo pyktis - tai pavydo ženklas. Pavydas verčia jaustis nepilnaverčiu, tai jausmas, kuris kyla, kai kitas atima iš tavęs tai, ko trokšti sau. Kaino auka atmetama. Pažeminimo ir ịskaudinimo negali paslèpti ar nuslopinti, nes Abelis viską matė (Nauta, 2009, p. 66). Pirmaisiais krikščionybės amžiais apie šiuos du aukas aukojančius brolius taip pasakota: Abelis yra ant kalno, o žemdirbys Kainas - slènyje. Abelio aukos dūmai kyla tiesiai ị dangų ir neša jo auką Viešpačiui. Kaino aukos dūmai sklaidosi pažemiu ir aukščiau nepakyla. Be kitu aiškinimų, įdomi šiame pasakojime glūdinti dvasinè prasmè: Kainas nebesugeba skaityti nei kūrinijos, nei laiko ženklų, jis gyvena taip, tarsi visi rengtų prieš jị sąmokslą. Tai - prieš save patị sukilęs žmogus, matantis tiktai save ir nebesuvokiantis nei tikrovès, nei istorijos, visa ko bijantis bei visa ką įtariantis. Kiekvieną ženklą jis priima kaip grèsmę: mato kitą ir jị suvokia kaip turintị kẻslų savo atžvilgiu. Tas kitas gali turèti pačių geriausių norų, bet jie priimami kaip išdavystė ar grèsmè. Viso to priežastis - Viešpaties atsisakymas priimti Kaino auką: jis tartum panūsta teisti patị Dievą. Bet juk Dievas yra laisvas, jis - Asmuo, tad veikia laisvai, beje, laisve visada yra jo meilès matmuo. Kas nesugeba to priimti, teisia Dievą, kartu atskleidžia savyje nykstant meilès pradą (Gudaitytè, 2007, p. 84). „Pamoksle apie šnairavimą ir 
tinginystę, sakytame Salantuose per Sekmines 1815 metais“113 kun. J. Pabrěža kelia klausimą apie šnairavimo, pavydaus žiūrẻjimo ị artimą žalą.

Šnairuotojas kenkia sau ir kūnui, ir dvasiai. Žalą kūnui, nes šnairuotojas džiūsta patsai savo širdyje nuo pavydaus šnairavimo, ir kaip kirminas gadina medị, kaip rūdis gadina geležị, taip pavydus žiūrejjimas gadina sveikatą žmogaus. (...) Nes tai Dievas tau skelbia, jog dèl tavo piktos akies nenustos būti gerą darančiam tam, kam nori (Mt 20, 15). ${ }^{14}$

Tai sakydamas pamokslininkas nurodo į Evangelijos pagal Matą žodžius: „Nejaugi man nevalia tvarkyti savo reikalų, kaip noriu?! Ar todèl šnairuoji, kad aš geras?!“ (Mt 20, 15). Pavydus žiūrèjimas - tai liūdesys, kilęs dèl kito žmogaus turimo turto, ir besaikis troškimas - net ir neteisètai - ji pasisavinti. Kaip sako J. Pabrèža, per pavydų žvilgsnį Kainas puolè ị nuodėmę, kurios slegiamą kaltę jautè visą gyvenimą:

Nukentejo pats Kainas, nes per visą savo gyvenimą turejo nešioti savyje Dievo bausmę. ${ }^{15}$

Kai pavydžiai žvelgiant trokštama artimui didelio blogio, daroma mirtinoji nuodėmè. Bažnyčios mokymas teigia, kad pavydas gimdo neapykantą, apkalbas, šmeižtą, džiaugsmą dẻl artimo nelaimès ir susikrimtimą dèl jo sèkmès (Katalikų Bažnyčios Katekizmas, 2012, nr. 2539).

13 Pamokstós Apey Óżwidieiyma yr Tingyni. - sakits Sałątusy ónt Sekmyniu. Metusy 1815, p. 379-390.

14 „Óżwidelniks yszkadyi sau yr ónt kuna yr ónt Duszys. Yszkadyi ónt kuna, nes óżwidelniks dziun patsay szyrdie sawa ysz óżwidieiyma, yr kaypo kyrmys gadyn medi; kaypo rudis gadyn gelzi, teyp óżwidieiyms gadyn sweykata żmogaus. ...Nes szytay Dyiws tau apznaymyi, iog dieley tawa pyktos akyis neparstos buty geray darączió tam, kam nor (:Matth. 20.15)“. Pamoksłós Apey Óżwidieiyma yr Tingyni. - sakits Sałątusy ónt Sekmyniu. Metusy 1815, p. 382.

15 „Óżyszkadyiy sau Kains, nes par wysa giwenyma sawa tórieiy neszioty ónt sawys karony Dyiwa“. Pamokstós Apey Óżwidieiyma yr Tingyni. - sakits Sałątusy ónt Sekmyniu. Metusy 1815, p. 382. 


\section{Kuo bloga šventvagiška išpažintis?}

Per išpažintị reikia tiksliai, nuoširdžiai pasakyti visas nuodèmes, išpažinti konkrečius nuodėmingus veiksmus, o ne tik bendrus polinkius. Privalu išpažinti visas sunkiąsias nuodèmes, t. y. visus su svarbiu dalyku susijusius sąmoningus ir laisva valia atliktus veiksmus. Tas, kuris iš gėdos ar baimès nuslepia nuodèmę arba stengiasi sumenkinti jos sunkumą, bergždžiai bando apgauti Dievą, jo atlikta išpažintis šventvagiška. Kun. J. Pabrěža „Pamoksle apie šventvagišką išpažintį, sakytame Švėkšnoje per 40 dienų atlaidus 1824 metais ${ }^{\text {"16 }}$, kalba apie šventvagiškos išpažinties blogi žmogui.

Labai daug žalos daro šventvagiška išpažintis žmogui. 1. Per tokią Išpažintị kunigo absoliucija nuodèmių neatleidžia. (...) 6. Užtraukia žmogui didelę Dievo bausmę tiek šiame pasaulyje, tiek po mirties. ${ }^{17}$

Patiriamą sąžinès neramumą po šventvagiškos išpažinties kun. J. Pabrèža iliustruoja pavyzdžiu, nurodydamas Kaino kaltès potyrị. Kaltas žmogus tarsi turi kažką savyje, kas iš šono jị stebi ir teisia.

Kiekvienas šventvagis galimai neramią sąžinę turi, kaip Kainas, kuris užmušè savo tikraji brolị Abelị, o prieš Viešpatị Dievą savo nuodèmès išsigynè, patyre baisų neramumą savyje ( $\operatorname{Pr} 4,9-16)$. Išbėgo Kainas lauk iš savo tèvo namų ir valkiojosi po svetimus kraštus. Ir nors niekas paskui jo nesigynè, jis vienok slapstèsi ir bijojo, kad kas jo paties neužmuštų, nes jo nuodèmé visados jam stovejo akyse ir visados jam rūpejjo. Tas pats dedasi su tuo, kuris atliko šventvagišką išpažintị. ${ }^{18}$

16 Pamokstós Apey Spawiedny Szwętwagyszna. Sakits Szwiekszno ónt Atposku 40.Adinu. Metusy 1824.

17 „Łabay daug pykta dara Spawiedne Szwętwagyszna dieł żmogaus: 1ํ iog par toky Spawiedny Absalocyje Kónyga grieku neatleyd. (...) 6º́ Ótrauk ónt żmogaus strosznes karones Dyiwa tad ónt szio Szwieta, tad po smerty." Pamokstós Apey Spawiedny Szwętwagyszna. Sakits Szwiekszno ónt Atposku 40.Adinu. Metusy 1824 , p. 465.

18 „Kożnós Szwętwagyszis padabny nespakaynóma sumnenys datyr, kayp Kains, kórs óżmuszys tykróuji broli sawa Abló, o óżsyginys prisz pati Pona Dyiwa grieka sawa, datiry stroszniausy nespakaynóma ónt sawys (: Gen. 4.9. etc.) Yszbiega Kains łaukón ysz nómu Tiewa sawa, yr walkiojes po swetymus paszalus. 
Čia vèl kun. J. Pabrèža primena Pradžios knygos žodžius, kuriais perteikiamas nerimastingas Kaino būvis, kai nuodėmė neišsakyta, neišpažinta ir negautas atleidimas. Dvasinè kančia lydejjo Kainą, dvasinè įtampa ir kančia lydi žmogų, šventvagiškai šventusį Atgailos sakramentą. Likęs kaltės jautimas rodo, kad žmoguje tarsi kažkas sulaužyta, suardyta, kažkas, kas ji žeidžia (Ivanovienè, Juškienè, 2018, p. 114) ir nèra atitaisyta.

\section{Išvados}

Kun. J. Pabrèža pamokslų rinkinyje „Pamokslai vairingose materijose“ biblinị Kaino vardą mini 22 kartus. Iš šio rinkinio 48-ių pamokslų jis minimas 5-iuose:

- Pamoksle apie šnairavimą ir tinginystę, kuris sakytas Salantuose per Sekmines 1815 metais.

- Pamoksle apie Pirmo Dievo ịsakymo antrą dalị, tai yra apie tikèjimą, viltị, meilę ir Dievo garbę, kuris sakytas Salantuose 40 dienų atlaidų metu, per Sekmines, 1825 metais.

- Pamoksle apie Penktą Dievo įsakymą, kuris sakytas per Didiji jubiliejų Mosédyje 1826 metais.

- Pamoksle apie Dešimt Dievo įsakymų, kuris sakytas Mosèdyje per Didiji jubiliejų 1826 metais.

- Pamoksle apie šventvagišką išpažintį, kuris sakytas Švėkšnoje per 40 dienų atlaidus 1824 metais.

Kaino nuodėmės ir jo kaltės išgyvenimo pavyzdžiai pateikti aptariant asmens dvasinès gerovès klausimus:

- Kas neturi vilties būti išganytas?

- Kas užmušdamas kitą žmogų, nepadaro nuodèmès?

- Kodèl geisti svetimų daiktų yra blogai?

Yr norint nieks paskóu jo negynies, óns wyinok słapsties, yr byjojes, kad kas jo patyis neóżmusztu: nes grieks jo wysados jem stowieiy akysó, yr wysados jem rupieiy. - Tas pats dedas só tóumi, kórs atprowyi Spawiedny Szwętwagysznay.“ Pamokstós Apey Spawiedny Szwętwagyszna. Sakits Szwiekszno ónt Atposku 40.Adinu. Metusy 1824, p. 465. 
- Kokị blogị lemia pavydus šnairavimas ị kitą?

- Kuo bloga šventvagiška išpažintis?

Remdamiesi Biblijos pasakojimu apie Kainą ir šio pasakojimo pavyzdžiais kun. J. Pabrěžos pamoksluose matome, kad žmogus patiria nerimastingą kaltès išgyvenimą kaip pasąmoningą būseną, kurios veikiamas jaučia nesaugumą, bejègiškumą, dvasinę kančią, kaip gyvenimo prasmės stoką. Šis kaltės jausmas turi savo priežastį - nuodėmę, t. y. veikimą pasaulyje ne pagal prigimties dèsnius. Žmogiškoji prigimtis, atsiskyrusi nuo Dievo, nebetenka tvirto ontologinio egzistavimo pagrindo. Ją ištinka dvasinè nebūtis, kuri atsiskleidžia kaip apleistumas, izoliacija, vienatvè, taigi kaip atsidavimas Niekui, kuris taip įsiskverbia i žmogaus gyvenimą, kad jis nebesuvokia jo prasmès ir paskirties.

\section{Literatūra}

Ange, D. (2006). Atleidimas - dieviškoji chirurgija. Vilnius: Katalikų pasaulio leidiniai. Forte, B. (2002). Mažasis ịvadas i krikščionio gyvenima. Vilnius: Katalikų pasaulis. Gudaitytè, B. (2007). Savęs pažinimas - kelias ị Tikrają Tikrovę. Soter, Nr. 23, p. 71-90. Ivanovienè, V., Juškienè, V. (2018). Nerimo, kaip pirmapradès nuodėmès, raiška žmogaus savivokoje. Mokslo ir tikèjimo dialogai. Tiltai. Priedas: Mokslo darbai, Nr. 48, p. 107-133.

Junior, N. (2020). The Mark of Cain and White Violence. Journal of Biblical Literature 139, No. 4, p. 661-673.

Katalikų Bažnyčios Katekizmas. (2012). Vilnius: Katalikų pasaulio leidiniai.

Kataliku Bažnyčios Katekizmas. Santrauka. (2007). Kaunas: Katalikų interneto tarnyba. Maceina, A. (2004). Raštai, T. 9. Vilnius: Margi raštai.

Madow, L. (1972). Anger. New York: Scribner's.

Mellinkoff, R. (1981). The Mark of Cain. University of California Press.

Misiūnienè, J. (2011). XV-XVIII amžių Biblijos Lietuvos nacionalinejje bibliotekoje. Bibliografija 2008-2009. Mokslo darbai, p. 55-81.

Narbekovas, A. (2004). Bioetika. Kaunas: VDU leidykla.

Nauta, R. (2009). Cain and Abel: Violence, Shame and Jealousy. Pastoral Psychol, Nr. 58, p. 65-71.

Neverdauskè, V. (2015). Katalikiškos asmens orumo sampratos svarba vyresniojo amžiaus žmoniu (65-70 m.) socialinès atskirties prevencijai. Magistro baigiamasis darbas. Kaunas: VDU Katalikų teologijos fakultetas. 
Oželis, R. (2012). Žmogaus pirmụjų nuodèmių ir dieviškojo Gailestingumo gimimo paralelès Biblijoje. Res humanitariae, Nr. 12, p. 270-295.

Pamokslai vairingose materijose, sakyti Ambroziejaus Pabrėžos. (2020). Vilnius: Lietuvių kalbos institutas. (Pamoksłay Wayringosy materyjosy ąt rožniu wyitu, iwayriusy taykusy Sakity par Kónyga Ambroźiejó Pabreża Tercyjorió Zokana Szwęta Tiewa Praćźyszkaus.)

Philippe, J. (2005). Vidinè laisvè. Vilnius: Katalikų pasaulio leidiniai.

Plett, L. (2013). Dvasinès ligos. Schwäbisch Gmünd: Wasser des Lebens.

Popiežius Jonas Paulius II. (1995). Enciklika „Evangelium Vitae“ apie žmogaus gyvybès vertę bei neliečiamuma. Vilnius: Aidai.

Popiežius Pranciškus. (2018). Myletti kaip Dievas. Trečiadienio katechezès apie šei$m q$. Kaunas: Artuma, p. 27.

Savickij, A. (2012). Kataliku Bažnyčios mokymo ir šiuolaikinès bioetikos požiūris $i$ gyvybę. Magistro darbas. Vilnius: LEU Ugdymo mokslų fakultetas.

Tikèjimo mokslo kongregacija. (2000). Deklaracija „Dominus Iesus “ dèl Jèzaus Kristaus ir Bažnyčios vienatinumo bei ju išganomojo veikimo visuotinumo. Prieiga internete: https://www.vatican.va/roman_curia/congregations/cfaith/documents/ rc_con_cfaith_doc_20000806_dominus-iesus_lit.html [žiūrèta 2021-07-22].

Van Breda, A. D. (2007). Guilt \& Forgiveness. Prieiga internete: <www.adrian.vanbreda.org/theology/16_guilt_forgiveness.pdf $>$ [žiūrèta 2017-07-29].

What Does the Bible Say About... Repentance, Forgiveness \& Salvation. Prieiga internete: http://www.bibleplus.org/repentance/repentance.htm [žiūrèta 2020-07-06].

\section{EXAMPLES OF CAIN'S GUILT IN THE SERMONS BY PRIEST JURGIS PABRE் ŽA}

\section{Remigijus Oželis}

Summary

A person is an active being who at the same time experiences a disturbing feeling of guilt for his/her wrong actions. The experience of guilt spiritually oppresses and crushes the person. Man desires reconciliation: reconciliation 
with another, with himself, and with God. Overcoming guilt and feeling spiritual peace is a fundamental human endeavour.

One of the outstanding preachers of salvation was priest Jurgis Pabrèža (1771-1849). He was a man of wide interests, whose ambition was to serve people with all his might, to keep science and faith in close unity, to proclaim the word of God, so that we "receive salvation through our Lord Jesus Christ" (1 Thessalonians 5: 9). Speaking of human guilt and liberation from the oppressive feeling of guilt in his sermons, Fr. J. Pabreža provided the example of the story of Cain's experience of guilt. By the example of Cain's guilt, J. Pabrezza sought to free people from the state of uneasy guilt while delivering purposeful, time-and-place-appropriate sermons. Therefore, this article discusses examples of Cain's sinful state and experience of guilt in the collection of sermons "Sermons on Various Matters" by Fr. J. Pabrèža.

Fr. Jurgis Pabrèža mentions the biblical name of Cain 22 times in his sermon collection "Sermons on Various Matters". Of 48 sermons in this collection Cain is mentioned in 5 of them:

- The sermon on sneering and laziness given in Salantai on Pentecost 1815.

- The sermon on the second part of the First Commandment of God, that is, on faith, hope, love and the glory of God, delivered in Salantai during the 40 days of indulgence at Pentecost 1825.

- The sermon on the Fifth Commandment of God, given at the Great Jubilee in Mosedis in 1826.

- The sermon on the Ten Commandments of God, delivered in Mosèdis during the Great Jubilee in 1826.

- The sermon on blasphemous confession, given in Švèkšna during the 40 days of indulgence in 1824.

Examples of Cain's experience of sin and guilt are given when discussing the spiritual well-being of a person:

- Who has no hope to be saved?

- Who does not commit sin by killing another man?

- Why is it bad to desire what belongs to another? 
- What evil is there in a jealous sneer towards others?

- What is wrong with a blasphemous confession?

In the biblical story of Cain and examples of this narrative in the sermons of Fr. J. Pabrèža we see that a person experiences a disturbing feeling of guilt as a subconscious state of insecurity, helplessness and spiritual suffering, and as a lack of meaning in life. This sense of guilt has its own cause - sin, i.e. acting in the world against the laws of nature. Human nature, separated from God, no longer has a solid ontological basis of existence. It faces spiritual nothingness that manifests itself as desolation, isolation, loneliness, and thus as a devotion to Nothing that so penetrates human life that he/she ceases to comprehend its meaning and purpose. 